\title{
岩石の衝擊破碎抵 抗*
}

\section{Fracturing Resistance of Rock under Impact}

Kazuro SASAKI, Norio YAMAKADO, Tomio SHOJI and Zen-iti SIOHARA

The PAGE impact test machine is generally used for the fracturing resistance or the toughness of rock; but the equipment which has used for this study, was an impact load measuring apparatus with wire strain gauge being equipped specially for the purpose.

Taking the impact drop test in testing the toughness of rock, the strain, which is the phenomena to be observed before the fracture caused by the impact, affects occasionally the fracturing resistance and accordingly the effect of measurement is not always matched to the actual resistance to be shown at the impact.

At the experiment, which was done applying the one stretch impact method, it was found that the fracturing resistance or the toughness of rock can be measured exactly as it occured.

\section{1. 緒言}

岩石のさく扎，爆破に詨しては，その硬度と靶性（衝 擊に対する破砕抵抗）が大き影響を及㴗すといわれて おり，この挴性の決定に当つては，ドロップテスト法， ショアー硬度計を用いる方法等が用いられるが，靱性試 験用ページ㣫撃試験機を用いるドロップテスト法が広く 用いられている。

ドロップテストはアンビル上に置いた一定の大きさの 岩石試料上に，下端が半径1 $\mathrm{cm}$ の球状をなす重量 $1 \mathrm{~kg} の$

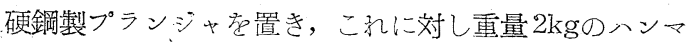
を, 最初1cmの高さより落下させ, 逐次その落下高さを $1 \mathrm{~cm}$ 宛増加して試料に㣫撃を与え, 試料が破砕された時 のハンマの落下高さを表わす $\mathrm{cm}$ 数をもつて, その試料 の靱性をあらわしている。

この試験法においては, 試料が破碎する迄ハンマの落

* 昭和 29 年 12 月 17 日受理

* 資源技術試験所 第 6 部

1) Standard method of test for toughness of rock. A. S. T. M. Designation D3-18,

2) R. Shepherd : Improving the Efficiency of Rotary Drilling of Shotholes, Transactions of the Inscitution of Mining Engineers. Ang. 1954, pp. 1029 1053.
下高さを順次 $1 \mathrm{~cm}$ 宛増加していく関係上，破研する迄に は相当量の歪が試料内に累積され，しかもこの累積歪は 岩種により，页破砕に至る迄の衝撃回数によつて異なる ものと考えられる。したがつて，この累積㱏は当然, 岩 石の㣫撃に対する破砕抵抗，すなわち淽性に影響を及涩 すと考えられるので，この様な方法では正確には岩石の 䩲性を効比することは出来好のではないか？ドロップ テントにはこの様な疑点があるので，新たにワイヤ・ス トレインゲージを利用した衝撃力測定装置を設計, 製作 しこれにより岩石の衝撃破砕抵抗につき研究する一方, 徒来のドロップテスト法につき検討した。

\section{2. 衝擊力測定裝置及び測定法}

この装置は，㣫撃力附加部と㣫撃力測定部よりなつ ている。附加部の構造及び寸法はペーシ㣫撃試験機と同 様である。

測定部は, 㣫撃力受感部, 增巾器, ブラウン管及び撮 影機よりなつている。内面にワイヤ・ストレイゲージを 貼付けてある中空円鋳型の受感部に㣫撃力が加われぱ， これは弾性的に圧縮され，ストレインゲーシの抵抗は変 化し電位差を生じる。この出力ね $\mathrm{CR}$ 結合の低周波増巾 


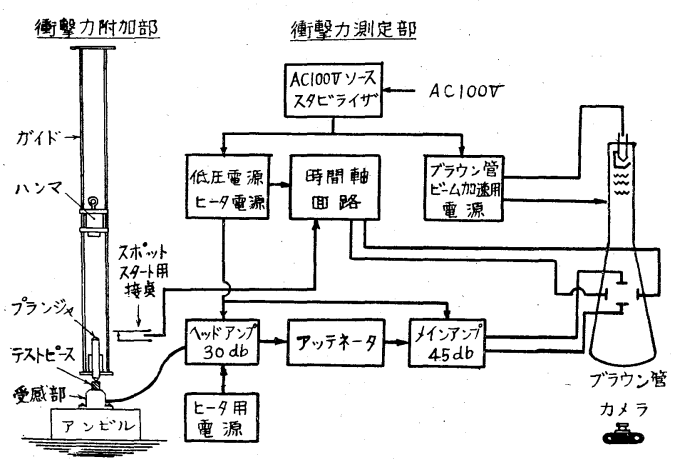

第1図衝擊破碎抵抗测定裝置機構図

器により增巾してブラウン管のY軸に大れる。この際， 観測現象は一打撃で終るため, これには単掃引引時間軸回 路な使用してある。ブラウン管は東芝製撮影用 $12 \mathrm{~F}-\mathrm{B} 11$ である。第 1 四は本装置の機構図を示したものである。

測定法としては，受感部上に，プランジャの下端がそ の中心線上にくる様に試料（標淮として直径22, 高芑22 $\mathrm{mm}$ の円鋳型のものを使用) 施設置し，ハンマをプラン ジャ上に落下させる。この際，ハンマの落下によりスポ ッ下スター下用接点が閉じると，ブラウン管のスポッ下 はスタートし，左より右へ約 $23 \mathrm{~m} / \mathrm{sec} の$ 速度で移動する (この速度は調節出来る)。その間にハンマがプランジャ に当り,試料に衝撃力が与去られれば受感部は圧縮され， この為に生ずる出力が Y軸に入り，ブラウン管上に一つ の波形があらわれる(第4 図参照)。この波形危写真に撮 り，公の波の高さより受感部に伝わつた衝撃力の大小を 比較する。

プランジャを通してハンマの打撃力が試料に伝わつた 場合, 試料に与えられた力が，公の試料虐破砕方るに要 ずる力ふりう小さい時は,試料に与えられた力の一部は， 試料の弾性変形，塑性変形等に用いられ，残りの力が受 感部に伝わり，これを弾性的に圧縮する一宁，プランジ ヤは反撥する。すなわち，受感部には試料に与えられた エネルギーより吸收ェネルギー（試料の弾性，塑性変形 等に使用されるエネルギー）觉差引いただけのエネルギ 一が伝わり，その大小に応した波形がブラウン管上に示 される。ハンマの打撃力が堌大して試料を破砕寸る場合 には，受感部には陚料破厒するに要したエネルギーが 伝達され，この際の波形より破砕抵抗を知ることが出来 る。

波形の撮影にはタクマf 3.5 付アサヒフレックスを使用 し，フィルムは富士 X一レィフィルム（間接撮影用）を 用いた。

\section{3. 衝撃力と波の高さとの関係}

受感部に異なつた㣫撃力が与えられれぱ，それに応じ て異つた波の高さ在得るが，テスト用ブランジャ（岩石

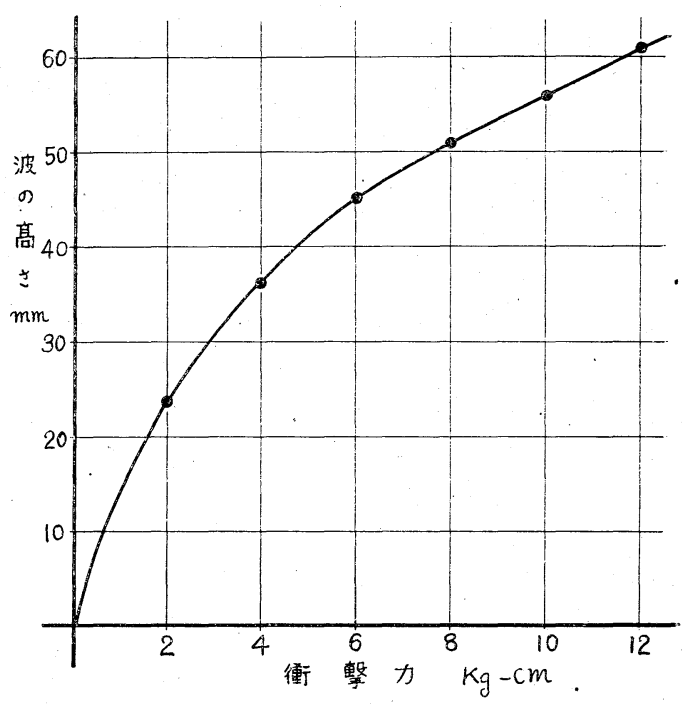

第2図衔㢣力と波の高さとの関你

試験用プランジャと同しく硬鋼製にして，その直径，そ の他は同様であるが，その長さは，岩石試験用のものよ り $22 \mathrm{~mm}$ 長くなつている) 觉用い，プランジャに与えた 㣫撃力と波の高さとの関係它求めた結果は第 2 図の如く である。もちろん,この踇は，ハンマがプランジャに与 えた衝撃力のす心゙てが受感部に伝達されるわけではない が，一店この試験結果堂基準として，以下の試験におけ る㣫撃力対比の基準とした。

\section{4. 衝擊力及び試料の大きさを変えた 場合の破碎抵抗の变化}

試料にある程度以上の㣫撃力を与毟学ならぱ,これは

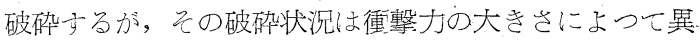
なり，㣫撃力が試料を破砕するに要する最小エネルギー に等しければこれれはほほ中心線上を通る平面に沿つて 2 つに割れる。衝撃力がこれ以上の湯合には，試料は更 に細かく破砕される一方，遠方へとはさされる。メシマの 落下高さ距変えた場合の破砕抵抗の変化觉知る為に, 各 種の同一岩石試料（直径 $22 \mathrm{~mm}$ 高さ $22 \mathrm{~mm}$ の円鋳型）に 対し，ハンマをとれぞれ $10,15,20,25 \mathrm{~cm}$ の高さょり 落下させブラウン管上の波の高导測定した結果の一例 は第3 龱の如くである。これは，ある砂岩について行つ た試験結果であるが，この試料はハンマを $10 \mathrm{~cm}$ の高さ より落下させた場合に丁度 $2 つ に$ 割れる。この結果より, 第 1 波の高さは，測定範围内においてはハンマの落下高 さ，すなわち衝撃力が变化しても $2 つ に$ 割れた場合と等 しく，一定であることがわかる。しかし第2波は，ハン マの落下高さの增大に応じて漸次高くなつている。波形 の一例を走すならば第 4 园の如くであり，(1)〜 ( 4 )は それぞれハシマの落下高さが $10,15,20,25 \mathrm{~cm}$ の場合 のものであるが，それぞれの試料は2(ひび割れを含む) 


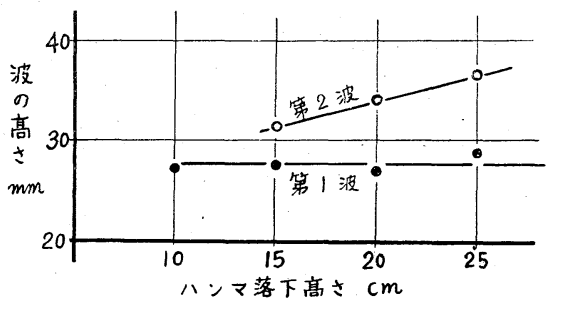

第3図 ハンマ落 妾さ之 波の高さ 乞の閔係

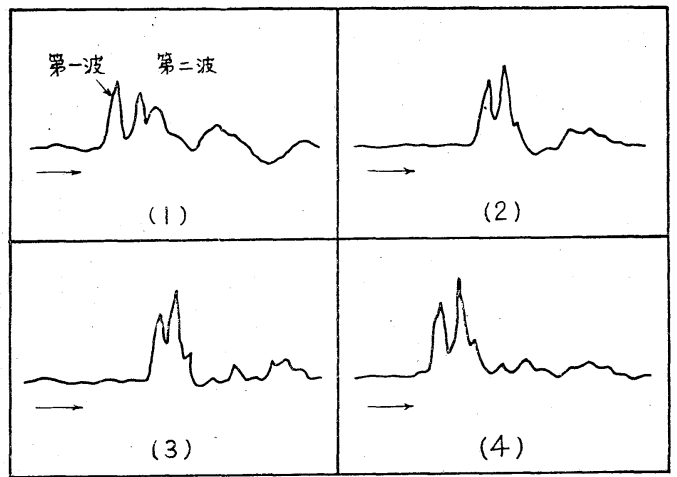

第4図 ハンマ落下高さ变えた場合の波形

3，4，4 個に割れるもの多く，ハンマの落下高さが大に なる程微細粒子が多くなつている。以上の現象は, 試料 にプランジャを通してある程度以上の㣫撃功与えられ

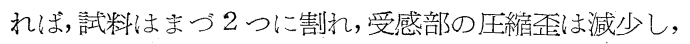
その為に上皁過程にあつた波は下降し始める為と思われ る。衝撃力が更に大なる場合には，プランジャは更に試 料に衝撃力字与え，これ在更に細かく破砕古方。この時 の破砕エネルギーは第2 波以下にあらわれるものと考光 られる。したがつて，1回の打撃にて試料交破砕し，そ の時の第 I波の高さを測定して破砕エネルギーを対比す る一この方法芭一撃破砕試験法と呼ぶこととする一 ならば，衝撃力の大きさ，試料の破砕状沉の如何に拘ら ず，試料走2つに割るに要したエネルギーを対比するこ とが出来, 岩石の衝撃破砕抵抗苍知ることが出来ると考 えられる。

前述の試験に括いては, 試料は直径 22 , 高さ $22 \mathrm{~mm} の$ 円鋳型のもの它使用したが, 試料の大きさ存变えた場合, これを2つに割るに要方る破砕エネルギーの变化を知る 為に，大きさの異つた試料（何れも直径と高さは等しい 円鋳型）を用、，一撃破砕試験法により破砕抵抗を対比 した結果は第 5 目の如くであり，破砕抵抗は，破砕によ つて生じた表面積（この場合は直径の２乗）にほほ比例 することを示している。したがつて，ドロップテストに おらてて直径 25 , 高さ $25 \mathrm{~mm}$ の円鋳型試料を標準とし て使用しているが，一撃破砕試験法によるならば，試料

3) Leonard Obert : S. L. Windes and Wilbur I. Duva11 : Standardized tests for determining the physical properties of mine rock. Bureau of Mine, R. I. 3891 Aug. 1946.

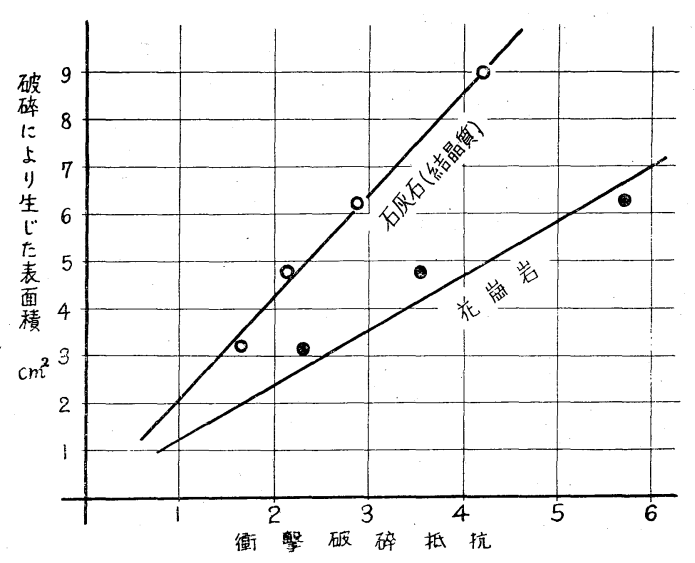

第 5 図，破碎により新たに生じた表面䅡と衝擊破碎 抵抗との閣你

の大きさは必ずしもこれと同じにしなくとも，任意の寸 法のものに換算出来るので, 以下の試験にはすべて直径 22 , 高さ $22 \mathrm{~mm}$ のもの支使用した。

Leonard Obert 氏等は，ドロップテストにより大き さの異つた試料を用いて衝撃破砕抵抗の变化学測定した 結果,これ等の間には一定の関係は見出されなかつたと 述心ているが，これは，ドロップテストに扮いては試料 の大きさによつて残留歪の破砕に更ぼす影鄉が異なり， これが測定值に影響を及ぼした為と思われる。

\section{5.ドロップテストにおける吸收 エネルギーの変化}

同一岩石試料に対し,1回では破砕しない程度の等しい 衝撃力支，これが破砕与る迄繰返し与え，その時の破砕 エネルギー存測定する一方, 同じ試料につき一撃破砕試 験法により破砕エネルギーを測定し両者の值を対比した 結果, 前者は後者よりるかなり小さな值を得た。これは 先の打撃による歪が漸次累積され，この累積歪が破砕抵 抗に影響を及浛したものと考えられるが，ドロップテス トの如く， ハンマの落下高さ学 $1 \mathrm{~cm}$ 宛増加させた湯合， 吸収エネルギーが, 㣫撃才の大きさ, 岩種によつてどの 様に変化し，䍗積㺯の影響が゙の程度に現われるかを知 る為にドロップテストに際し，それぞれ吸収ェネルギ 一を測定した結果を示せは第6図の如くである。この四 より明らかなる如く, 各㣫撃力に対与る吸収ェネルギー は，岩種により異なり，変輝緑岩の様なものに打いては 小さく，砂岩の様なものに扎てては大きい。吸収ェネル ギーの大きな岩石の破砕面をみるに，第7図の如く，プ ランジャの当つた所は，契状に岩石が粉砕されて抢り， これが圧入された様な状態を示しているが，花崗岩等に はこの楔は見られない。砂岩の様な岩石の吸収ェネルギ 一が大きいのは, 衝撃力の一部がこの粉砕圈をつくるの に用いられているのも一つの原因と考えられる。又ドロ 


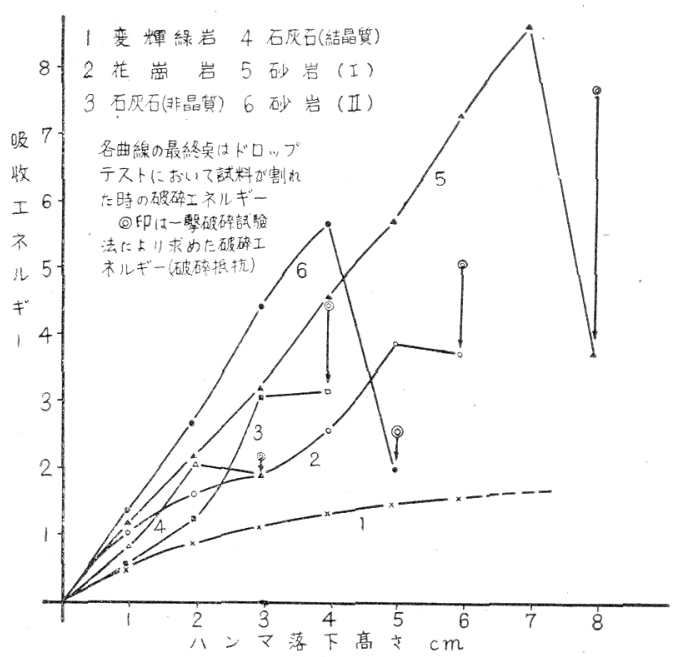

第6図ドロップテストの各打揧に和ける吸收 エネルギー

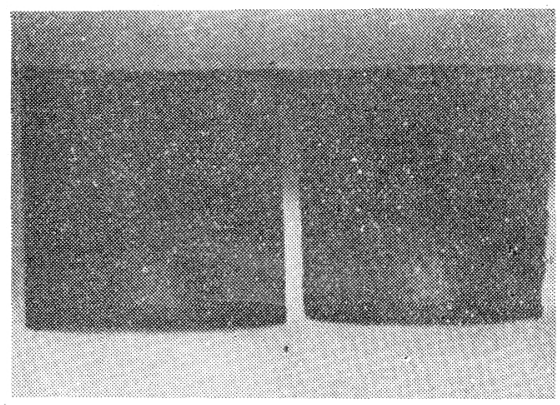

第 7 図 破碳面 の 1 例

ツプテストにより圾粼虏破确した時の破础エネルギー

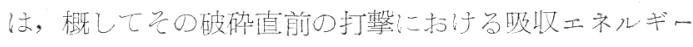
よりも小さい值在示しているが、これ破砕に至るまで の打撃により試料内に歪加生じ，これが㣫撃破砕抵抗に 影響存改傜した為である。征つて，破砕エネルギーと破 确直前の打撃に抢け名昅取土ネルギーとの差の大きいる

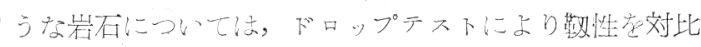
すること蜉当ではないと思われる。

\section{6.ドロップテストによる鞄性と一撃破碎 試験による鞀性との比較}

上述の如く，ドロップ䒘トの場合には，破砕に至吕

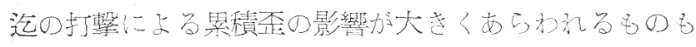

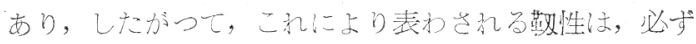
しも一揧破砕試験法により測定した靪性とは比例しない と考觉られるので, 数種の岩不につき, 臬径文び高さが共
第1表 ドロップテスト法及び一㨻破碎試験法に より求めた靱性り比較

\begin{tabular}{|c|c|c|c|c|}
\hline \multirow[b]{2}{*}{ 岩 石 名 } & \multicolumn{2}{|c|}{ ドロップテスト } & \multicolumn{2}{|c|}{ 一撃破碎試験 } \\
\hline & 䩲性 & 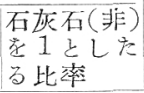 & 墐性 & 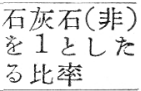 \\
\hline 変 輝 線 岩 & 14 & 3.5 & 15.1 & 3.4 \\
\hline 花爯閃綠岩 & 9 & 2.2 & 7.3 & 1.6 \\
\hline 仯 岩 (I) & 9 & 2.2 & 7.7 & 1.7 \\
\hline & 6 & 1.5 & 5.1 & 1.1 \\
\hline 岩 (II) & 5 & 1.3 & 2.4 & 0.5 \\
\hline 石灰石(非晶筫) & 4 & 1.0 & 4.5 & 1.0 \\
\hline 石灰石(絬晶質) & 3 & 0.8 & 2.2 & 0.5 \\
\hline
\end{tabular}

に $22 \mathrm{~mm}$ の試料党用い、ドロップテスト法と一揧破砕 試験法により，䩓性老求めた結果は第1表の如くである。 この表より明らかであるが，両試験法により表わされる 敬性结大体同梯なる傾间告示しているが，中にはその順 位の逆になのているものも見受けられる。この様にドロ

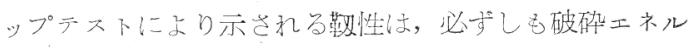

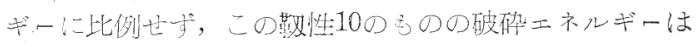
鞂性 50 ものの2 倍になるると限らないので, この值を 岩石のさく扎，爆破之直接結びっ!ナて考光るのは妥当で はない様に思和る。

\section{7. 結}

論

ワイヤ・ストレインゲージ苍利用した㣫撃力測定装置

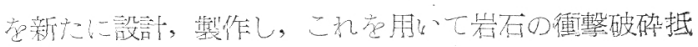
抗につき研究した。

円鉡型の岩石試料に対し，下端が球状をなしたプラン

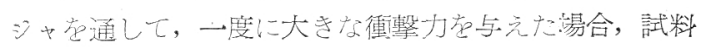
は第一段階で，大体試料の中心線趸通当平面に沿つて 2 つに割れ，次の段階で更に細かく割れるものと考元られ， この第一段階で 2 つ劃れる時の破砕抵抗は, 㣫撃力の 大きさ，破砕状沉の如何に㧦らず一定であり，又この破 砕抵抗はは经破砕によつて新たに生した破砕表面積に比 例一而。

ドロップチストによつて岩不の敬性を対比古る場合に は，破华に至るまでの打撃により生ずる累積枉が，破砕 抵抗に大きく影響圭及ぼ主ものもあり，これにより示さ

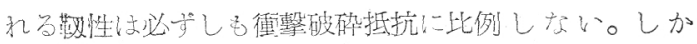

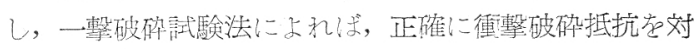
比子ることが出来ると考岳られる。

終りに, 本研究に当り試験装置の製作に対し御援助在 賜つた早川鉄工社長早川市蔵氏走はしめ, 岩石試料を提 供导れた各位に対し，深く感謝子る次第である。 